\title{
Multielemental analysis of 20 mushroom species growing near a heavily trafficked road in Poland
}

\author{
M. Mleczek ${ }^{1}$ • P. Niedzielski ${ }^{2}$ - P. Kalač $\check{\check{c}}^{3}$ A. Budka ${ }^{4} \cdot$ M. Siwulski ${ }^{5}$ M. Gąsecka ${ }^{1}$ •

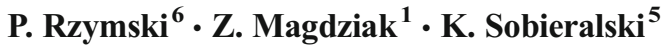

Received: 3 February 2016/Accepted: 25 April 2016/Published online: 7 May 2016

(C) The Author(s) 2016. This article is published with open access at Springerlink.com

\begin{abstract}
The aim of this work was to compare 10 mostly edible aboveground and 10 wood-growing mushroom species collected near a heavily trafficked road (approximately 28,000 vehicles per $24 \mathrm{~h}$ ) in Poland with regard to their capacity to accumulate 26 trace elements (Ag, Al, As, Au, B, Ba, Bi, Cd, $\mathrm{Co}, \mathrm{Cr}, \mathrm{Cu}, \mathrm{Fe}, \mathrm{Ga}, \mathrm{Ge}, \mathrm{In}, \mathrm{Li}, \mathrm{Mn}, \mathrm{Ni}, \mathrm{Pb}, \mathrm{Re}, \mathrm{Sb}, \mathrm{Se}, \mathrm{Sr}, \mathrm{Te}$, $\mathrm{Tl}$, and $\mathrm{Zn}$ ) in their fruit bodies in order to illustrate mushroom diversity in element accumulation. All analyses were performed using an inductively coupled plasma optical emission spectrometry (ICP-OES) spectrometer in synchronous dual view mode. The aboveground species had significantly higher levels of 12 elements, including $\mathrm{Ag}, \mathrm{As}, \mathrm{Pb}$, and $\mathrm{Se}$, compared to the wood-growing species. An opposite relationship was
\end{abstract}

Responsible editor: Philippe Garrigues

Electronic supplementary material The online version of this article (doi:10.1007/s11356-016-6760-8) contains supplementary material, which is available to authorized users.

M. Mleczek

mirekmm@up.poznan.pl

1 Department of Chemistry, Poznań University of Life Sciences, Poznań, Poland

2 Faculty of Chemistry, Adam Mickiewicz University in Poznań, Poznań, Poland

3 Department of Applied Chemistry, Faculty of Agriculture, University of South Bohemia, České Budějovice, Czech Republic

4 Department of Mathematical and Statistical Methods, Poznań University of Life Sciences, Poznań, Poland

5 Department of Vegetable Crops, Poznań University of Life Sciences, Poznań, Poland

6 Department of Environmental Medicine, Poznań University of Medical Sciences, Poznań, Poland observed only for $\mathrm{Au}, \mathrm{Ba}$, and $\mathrm{Sr}$. The results of principal component analysis (PCA) and hierarchical cluster analysis (HCA) implied some new relationships among the analyzed species and elements. Of the analyzed mushroom species, lead content in Macrolepiota procera would seem to pose a health risk; however, at present knowledge regarding lead bioaccessibility from mushrooms is quite limited.

Keywords Contamination · Consumer health · Trace elements $\cdot$ Environment $\cdot$ Mushrooms

\section{Introduction}

Mushroom consumption is generally high in Eastern Europe and Asia. However, consumption of wild mushrooms collected from polluted areas may be associated with the risk of exposure to toxic elements (particularly $\mathrm{Cd}, \mathrm{Hg}, \mathrm{Pb}$, and $\mathrm{As}$ ) being introduced to the human body. The content of trace elements in wild growing mushroom species, both edible and inedible, has been reported in numerous articles (for an overview of data, see reviews of Kalač and Svoboda (2000), Kalač (2010), and Falandysz and Borovička (2013)) and some recent papers, e.g., Kaya and Bag (2010), Ayaz et al. (2011), Sarikurkcu et al. (2015), Yin et al. (2012), or Mleczek et al. (2015a). Mushrooms were analyzed either as one species or as a comparison of many species, e.g., in a study of Borovička and Řanda (2007), where 130 species were compared. Additionally, wild growing mushroom species have been characterized on the basis of several elements, rarely on the content of selected forms (chemical species) only (e.g., Falandysz et al. 2007; Niedzielski et al. 2013) or based on a multielemental analysis (e.g., Gucia et al. 2012a; Kojta et al. 2012). Mushrooms have been collected from both unpolluted (e.g., Falandysz et al. 2012) and polluted areas (e.g., Svoboda 
et al. 2006; Radulescu et al. 2010; Árvay et al. 2014; Mleczek et al. 2015b).

Variability in the chemical composition of mushrooms within a species is greater than that of plants, much more so than within cultivars of a crop. Each individual fruit body can result from the cross-breeding of different hyphae and so presents a distinct genotype. Contents of a trace element in a mushroom species therefore vary widely, even by as much as 1 order of magnitude. Mushroom species, but most probably not genus, level of substrate composition, and local pollution with trace elements are the principal factors affecting trace element level in fruit bodies. The lifetime of most fruit bodies is usually only 10-14 days. Thus the role of fruit body age and size is of less importance owing to the limited proportion of contaminants originating from atmospheric depositions. However, this role may increase in some wood-growing species that have a longer lifespan than is usual in aboveground species (for detailed information, see reviews of Kalač and Svoboda (2000), Kalač (2010), and Falandysz and Borovička (2013)).

Mushrooms not only accumulate elements from underlying substrate but also from host trees depending on the specificity of species. Elements detrimental to humans originate from both natural sources and anthropogenic activities. Motor transport delivers significant amounts of both gaseous pollutants and selected elements, which generally negatively influence human health (Künzli et al. 2000) and contribute to changes in climate (EPA 2015). In Poland, apart from the sale of cultivated mushrooms in shops, wild growing mushroom species are frequently sold along roadsides and in street markets. Therefore, the aim of this study was to illustrate the diversity of 10 aboveground mushroom species and 10 wood-growing species, collected near a busy trunk road, in the accumulation 26 trace elements: silver $(\mathrm{Ag})$, aluminum $(\mathrm{Al})$, arsenic $(\mathrm{As})$, gold $(\mathrm{Au})$, boron $(\mathrm{B})$, barium $(\mathrm{Ba})$, bismuth (Bi), cadmium $(\mathrm{Cd})$, cobalt $(\mathrm{Co})$, chromium $(\mathrm{Cr})$, copper $(\mathrm{Cu})$, iron $(\mathrm{Fe})$, gallium $(\mathrm{Ga})$, germanium $(\mathrm{Ge})$, indium $(\mathrm{In})$, lithium $(\mathrm{Li})$, manganese $(\mathrm{Mn})$, nickel $(\mathrm{Ni})$, lead $(\mathrm{Pb})$, rhenium $(\mathrm{Re})$, antimony ( $\mathrm{Sb})$, selenium (Se), strontium ( $\mathrm{Sr}$ ), tellurium (Te), thallium ( $\mathrm{Tl}$ ), and zinc ( $\mathrm{Zn})$. The determined content of these elements in the fruit bodies of the mushrooms also allowed an assessment to be made of the health risks associated with the consumption of mushrooms collected near frequented roads.

\section{Materials and methods}

\section{Experimental material}

This work continues the theme of our previous paper (Mleczek et al. 2016), in which we analyzed the content of Platinum Group Elements (PGEs) and Rare Earth Elements (REEs) in the same 20 mushroom species growing near (up to $40 \mathrm{~m}$ ) the S11, a heavily trafficked road in Poland (about 28, 000 vehicles per $24 \mathrm{~h}$ ) (GDDKiA 2005, 2010). The sampled area lay up to $220 \mathrm{~m}$ from the localization point described by coordinates $52^{\circ} 16^{\prime} 50.75^{\prime \prime} \mathrm{N}, 17^{\circ} 03^{\prime} 43.31^{\prime \prime} \mathrm{E}$ (Fig. 1).

Fig. 1 Map of the sampled area

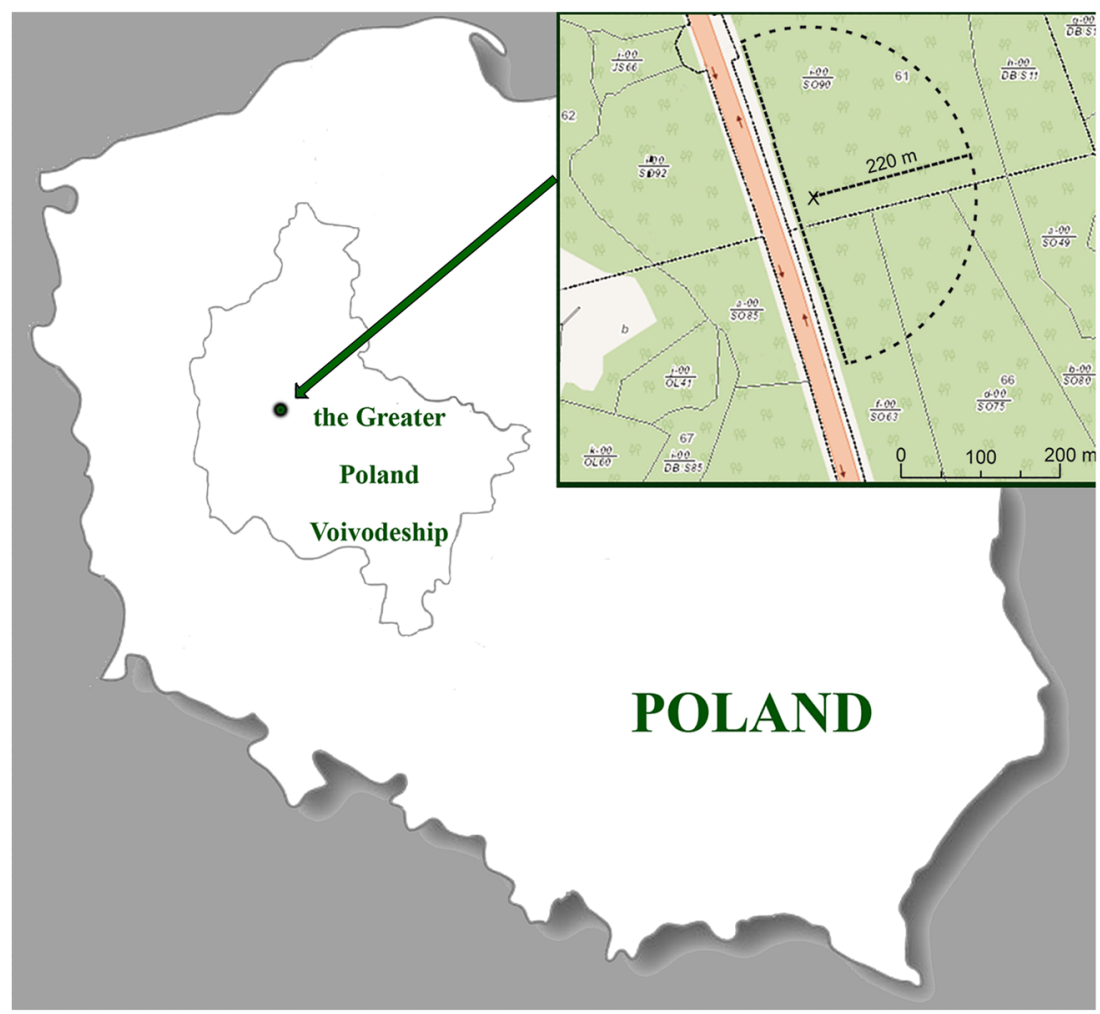


For 3 weeks prior to the day of sample collection, the prevailing direction of winds was south-east with a mean speed $1 \mathrm{~m} \mathrm{~s}^{-1}$. It is worth noting that the direction of local winds is generally variable. The mean temperature was $10 \pm 1{ }^{\circ} \mathrm{C}$, atmospheric pressure $994 \pm 3 \mathrm{hPa}$, and relative humidity was 96 $\pm 1 \%$. According to data presented at the Voivodeship Environmental Protection Inspectorate in Poznań (http:// powietrze.poznan.wios.gov.pl/), concentration of nitric oxide (NO), nitrogen dioxide $\left(\mathrm{NO}_{2}\right)$, sulfur dioxide $\left(\mathrm{SO}_{2}\right)$, and ozone $\left(\mathrm{O}_{3}\right)$ was $1 \pm 3,21 \pm 6,1.1 \pm 0.4$, and $31 \pm 13 \mu \mathrm{g} \mathrm{m}^{-3}$, respectively. The mean concentration of particulate matter (PM10 - $10 \mu \mathrm{m}$ or less in diameter) was 16. All presented meteorological data were determined within $24 \mathrm{~h}$ of October 22,2014 , when the sampled, fully developed fruit bodies were collected at the same time. Mushroom species were collected from a mixed forest composed of four tree species: Acer L. (Sapindaceae), Acacia Mill. (Fabaceae s.l.), Pinus L. (Pinaceae Lindl.) being the main species, and Quercus L. (Fagaceae Dumort.). The main criteria for mushroom selection were their occurrence in a confined sampling area and proximity to a heavily trafficked road. This sampling location was selected from among six possible sites due to the greatest occurrence of mushroom fruit bodies being observed there over a period of 5 years. The altitude of experimental site ranged from 83 to $85 \mathrm{~m}$ above sea level.
Soils where mushrooms were collected were formed from outwash sands, and according to the Classification of Polish wood soils (Czępińska-Kamińska et al. 2000) they belong to rusty soils. The term has no direct equivalent in WRB international soil classification (IUSS Working Group WRB 2015).

The collected mushroom species were divided into two groups: aboveground mushroom species and wood-growing species (Table 1). The number of collected fruit bodies for each of the collected species is also given.

After the transport to the laboratory, all the bodies were carefully cleaned with distilled water using Milli-Q Advantage A10Water Purification Systems, Merck Millipore (Merck, Darmstadt, Germany) to exclude any external surface contamination. The collected materials were dried in an electric drying oven (SLW 53 STD, Pol-Eko, Wodzisław Śląski, Poland) for $96 \mathrm{~h}$ at $65 \pm 1{ }^{\circ} \mathrm{C}$ to a constant weight and powdered using a Cutting Boll Mill 200 (Retsch GmbH, Haan, Germany) for $2 \mathrm{~min}$.

\section{Analytical methods}

Accurately weighed samples of $0.300 \pm 0.001 \mathrm{~g}$ were digested with concentrated Suprapure (TM) (65\%) nitric acid (Merck, Darmstadt, Germany) in closed teflon containers in a microwave digestion system Mars 5 (CEM, Matthews, NC, USA).
Table 1 Analyzed mushroom species and their edibility

\begin{tabular}{|c|c|c|}
\hline Species & $\begin{array}{l}\text { Number of } \\
\text { samples }\end{array}$ & Edibility \\
\hline \multicolumn{3}{|l|}{ Wood-growing species } \\
\hline Armillaria mellea (Vahl) P. Kumm. & 5 & Edible \\
\hline Auricularia auricula-judae (Bull.) Quél. & 3 & Edible \\
\hline Flammulina velutipes (Curtis) Singer & 3 & Edible \\
\hline Ganoderma applanatum (Pers.) Pat. & 4 & Inedible \\
\hline Grifola frondosa (Dicks.) Gray & 3 & Edible \\
\hline Laetiporus sulphureus (Bull.) Murrill & 4 & Inedible \\
\hline Piptoporus betulinus (Bull.) P. Karst. & 4 & Inedible \\
\hline Pleurotus ostreatus (Jacq.) P. Kumm. & 5 & Edible \\
\hline Pleurotus spp. & 8 & Edible \\
\hline Polyporus squamosus (Huds.) Fr. & 4 & Edible \\
\hline \multicolumn{3}{|l|}{ Aboveground species } \\
\hline Cantharellus cibarius Fr. & 8 & Edible \\
\hline Laccaria amethystina (Huds.) Cooke & 4 & Edible \\
\hline Leccinum scabrum (Bull.) Gray & 5 & Edible \\
\hline Lepista gilva (Pers.) Pat. & 6 & Edible \\
\hline Lyophyllum fumosum (Pers.) P.D. Orton & 5 & Edible \\
\hline Macrolepiota procera (Scop.) Singer & 3 & Edible \\
\hline Paxillus involutus (Batsch) Fr. & 3 & Inedible \\
\hline Suillus bovinus (L.) Roussel & 11 & Edible \\
\hline Suillus luteus (L.) Roussel & 3 & Edible \\
\hline Tricholoma equestre (L.) P. Kumm. & 3 & Edible \\
\hline
\end{tabular}


The digest was then filtered through a paper filter (Qualitative Filter Papers, Grade 595: 4-7 $\mu \mathrm{m}$ (Whatman, Maidstone, UK)) and diluted to $15.0 \mathrm{~mL}$ with water (purified in an ion-exchange/reverse osmosis system (Millipore, Billerica, USA)).

All analyses were performed using an inductively coupled plasma optical emission spectrometry (ICP-OES) spectrometer (model 5100 Agilent, USA) in synchronous dual view (simultaneous axial and radial plasma observation) mode. Common conditions for the determination of 26 elements were as follows: RF power $1.2 \mathrm{~kW}$, nebulizer gas flow $0.7 \mathrm{~L} \mathrm{~min}^{-1}$, auxiliary gas flow $1.0 \mathrm{~L} \mathrm{~min}^{-1}$, plasma gas flow 12.0 $\mathrm{L} \mathrm{min}^{-1}$, CCD temperature $-40{ }^{\circ} \mathrm{C}$, viewing height for radial plasma observation $8 \mathrm{~mm}$, accusation time $5 \mathrm{~s}$, three replicates. Spectral conditions for optical emission detection are collected in Table S1 and S2 (Supplementary data).

Each of the individual fruit bodies was analyzed in triplicate. In order to consolidate the number of replications while maintaining randomization, a triple sampling with replacement from the pool of individuals found for each species was conducted. All trace element contents are given as milligram per kilogram dry matter (d.m.).

\section{Analytical quality control (QC) and quality assurance (QA)}

The detection limits were determined as 3-sigma criteria at the level of $0.01 \mathrm{mg} \mathrm{kg}^{-1} \mathrm{~d}$.m. for all the elements determined. The correlation coefficients for all calibration curves were higher than 0.9995 , the uncertainty level for the whole analytical process (including sample preparation) was $20 \%$. The traceability was checked using five reference materials (biological and geological); the results of the analysis of certified reference materials are included in Table S3 (Supplementary data). The recovery was acceptable for all the elements determined. For the quality control of the series of measurements, Shewards cards were used for in-laboratory reference material (real sample). The analysisto-analysis recovery was at the acceptable level of $80-120 \%$.

\section{Soil analysis}

Twenty samples of forest soil collected from the Ap genetic horizon (depth of 0-20 cm) within the mushroom collection site with a soil auger were placed in air tight polypropylene containers. Greenery (grass or moss) and material other than soil (leaves, stones) were removed. Soil samples were transported to the laboratory directly after their collection. The soil samples were dried on Petri dishes for $48 \mathrm{~h}$ to determine water content according to Standard PN-ISO 11465:1999. Dry samples were transferred to an agate mortar and ground using a Cutting Boll Mill 200 (Retsch GmbH, Haan, Germany). Three subsamples $(0.5 \mathrm{~g})$ for each of 35 samples were extracted with aqua regia, according to standard PN-ISO 11466:2002. The soil was characterized by pH (PN-
ISO 10390:1997), electrolytic conduction (PN-ISO 1265+ AC1:1997), redox potential (ISO 11271:2002), and total nitrogen content using the Kjeldahl method. Content of $\mathrm{K}$ was analyzed by the Egner-Riehm method, $\mathrm{Mg}$ according to Schachtschabel's method (Breś et al. 2009), while total organic carbon according to PN-ISO 14235:2003. Characteristics of soil where mushrooms were collected are shown in Table 2.

\section{Statistical analysis}

In the present study, the effect of the experimental factor (mushroom species) on the accumulation of elements was assessed. The mean values of the analyzed variables (element contents) were compared for aboveground and wood-growing mushroom species separately. The Hotelling-Lawley test for MANOVA was used in the analysis of the simultaneous influence of many variables. One-way ANOVA with the Fisher's test $(\alpha=0.05)$ was used for evaluation of the effects of individual elements. Pairwise differences of mean element contents in the studied mushrooms were evaluated using Tukey's method, which allowed the determination of homogenous groups $(\alpha=0.01)$. Additionally, the Welch Two-Sample $t$ test $(\alpha=0.05)$ was applied to determine significance of differences between the average accumulation of individual elements.

Principal component analysis, PCA, was used in order to discover relationships between independent variables (element accumulation).

In addition, Heatmap Analysis with dendrograms based on hierarchical cluster analysis (HCA) was used to demonstrate similarities and differences in the accumulation of 26 elements in both the studied mushroom groups. To show the similarities or differences with regard to all 26 element contents jointly between mushroom species within both groups (aboveground and wood-growing mushrooms), the obtained results were illustrated using a Heatmap Analysis, where two dimension variables were represented by colors (Figs. 3 and 5). In a similar way, correlations between particular element contents were analyzed in aboveground and wood-growing mushroom groups (Figs. 4 and 6). Cluster Analysis allowed the selection of mushroom species (Figs. 3 and 5) and analyzed elements (Figs. 4 and 6) in the way that the relation between observations inside the same group was shown to be possibly the highest, while between different groups it was the lowest. Using Ward Hierarchical Clustering and Euclidean distances, tree diagrams with cluster grouping were obtained.

\section{Results and discussion}

Overall data on the contents of 26 trace elements in 20 species are given in Table 3.

Trace elements in mushrooms have been considered mainly from two perspectives. The environmental view concerns 
Table 2 Element concentration [ $\mathrm{mg} \mathrm{kg}^{-1}$ dry matter] and physicochemical characteristics of soil in the sampling site and usual levels within Europe

\begin{tabular}{|c|c|c|}
\hline Element & Concentration & $\begin{array}{l}\text { Mean concentration } \\
\text { in European soils* }\end{array}$ \\
\hline $\mathrm{Ag}$ & $0.29 \pm 0.14$ & $0.30 \pm 0.23$ \\
\hline $\mathrm{Al}^{* *}$ & $2368 \pm 329$ & $10.50 \pm 4.46^{* * *}$ \\
\hline As & $0.74 \pm 0.51$ & $11.6 \pm 20.1$ \\
\hline $\mathrm{Au}$ & $0.98 \pm 0.35$ & nd \\
\hline B & $2.09 \pm 0.88$ & nd \\
\hline $\mathrm{Ba}$ & $22.6 \pm 3.49$ & $400 \pm 213$ \\
\hline $\mathrm{Bi}$ & $0.38 \pm 0.17$ & nd \\
\hline $\mathrm{C}$ & $1.27 \pm 0.31$ & $2.48 \pm 3.18$ \\
\hline $\mathrm{Ca}^{* *}$ & $0.03 \pm 0.01$ & $3.54 \pm 7.26^{* * *}$ \\
\hline $\mathrm{Cd}$ & $0.47 \pm 0.31$ & $0.28 \pm 0.71$ \\
\hline Co & $1.64 \pm 0.54$ & $10.4 \pm 13.3$ \\
\hline $\mathrm{Cr}$ & $4.12 \pm 1.09$ & $94.8 \pm 285$ \\
\hline $\mathrm{Cu}$ & $3.26 \pm 1.22$ & $17.3 \pm 19.0$ \\
\hline $\mathrm{Fe}^{* *}$ & $3263 \pm 452$ & $3.80 \pm 2.34 * * *$ \\
\hline $\mathrm{Ga}$ & $0.03 \pm 0.02$ & $13.1 \pm 6.07$ \\
\hline $\mathrm{Ge}$ & $0.05 \pm 0.03$ & nd \\
\hline In & $1.41 \pm 0.76$ & $0.05 \pm 0.03$ \\
\hline $\mathrm{K}^{* *}$ & $0.04 \pm 0.01$ & $2.02 \pm 0.95^{* * *}$ \\
\hline $\mathrm{Li}$ & $0.76 \pm 0.29$ & nd \\
\hline $\mathrm{Mg}^{* *}$ & $0.05 \pm 0.02$ & $1.18 \pm 1.73^{* * *}$ \\
\hline $\mathrm{Mn}$ & $112 \pm 34$ & $0.08 \pm 0.07 * * *$ \\
\hline $\mathrm{N}$ & $0.04 \pm 0.03$ & nd \\
\hline $\mathrm{Na}$ & $186 \pm 42$ & $1.15 \pm 0.95^{* * *}$ \\
\hline $\mathrm{Ni}$ & $2.82 \pm 1.05$ & $37.3 \pm 136$ \\
\hline $\mathrm{P}^{* *}$ & $0.03 \pm 0.01$ & $0.15 \pm 0.12 * * *$ \\
\hline $\mathrm{Pb}$ & $7.97 \pm 2.87$ & $32.6 \pm 56.9$ \\
\hline $\operatorname{Re}$ & $0.21 \pm 0.13$ & nd \\
\hline $\mathrm{Sb}$ & $0.19 \pm 0.10$ & $1.0 \pm 2.0$ \\
\hline $\mathrm{Se}$ & $0.13 \pm 0.07$ & nd \\
\hline $\mathrm{Sr}$ & $8.88 \pm 3.14$ & $130 \pm 153$ \\
\hline $\mathrm{Te}$ & $0.62 \pm 0.26$ & $0.04 \pm 0.05$ \\
\hline $\mathrm{Tl}$ & $0.13 \pm 0.08$ & $0.82 \pm 1.02$ \\
\hline $\mathrm{Zn}$ & $15.39 \pm 3.68$ & $68 \pm 141$ \\
\hline Parameter & Unit & value \\
\hline $\mathrm{pH}\left(\mathrm{H}_{2} \mathrm{O}\right)$ & - & $5.41 \pm 0.09$ \\
\hline Eh & $\mathrm{mV}$ & $274 \pm 42$ \\
\hline Conductivity & $\mathrm{mS} \mathrm{m}^{-1}$ & $89 \pm 31$ \\
\hline
\end{tabular}

$n d$ no data

${ }^{\text {a }}$ According to Geochemical Atlas of Europe (Salminen et al. 2005)

${ }^{\mathrm{b}}$ Values in percent

${ }^{\mathrm{c}}$ Calculated for $\mathrm{Al}_{2} \mathrm{O}_{3}, \mathrm{CaO}, \mathrm{Fe}_{2} \mathrm{O}_{3}, \mathrm{~K}_{2} \mathrm{O}, \mathrm{MgO}, \mathrm{MnO}$, and $\mathrm{P}_{2} \mathrm{O}_{5}$, respectively

factors that affect bioaccumulation of individual trace elements in both mycelium and fruit bodies, particularly the role of such processes within mycorrhiza. Attempts to utilize the fruit bodies of some species as biomarkers of local contamination with various trace elements culminated during the 1980s and was gradually abandoned with no selection of any credible species (Wondratschek and Röder 1993). The second perspective deals with health and nutritional effects, in particular the detrimental elements $\mathrm{Cd}, \mathrm{Hg}, \mathrm{Pb}, \mathrm{Ag}$, and $\mathrm{As}$ in edible species. A connected aspect, the content of nutritionally required trace elements (particularly Se), has been problematic due to a virtual lack of knowledge of their bioaccessibility and bioavailability in humans.

There occur significant inter-year differences in trace metal contents within individual mushroom species. This has repeatedly been observed in mushrooms collected from the same site over the course of several years, e.g., by Chojnacka et al. (2013) in Xerocomus subtomentosus, Chudzyński et al. (2013) in Suillus grevillei, Gucia et al. (2012b) in Macrolepiota procera, and Zhang et al. (2010) in Boletus edulis. The cited works are based on an assumption that fruit bodies are formed by a steady mycelium. However, more mycelia of the same species can be present at the sampling site. A hypothesis was put forward that element levels in wild growing mushrooms considerably elevate with the increasing age of mycelium and protracted time lag between the fructifications (Kalač 2010).

Comparing the mean contents of both the mushroom groups gathered in Table 3, it can be seen that the aboveground species had a significantly higher mean level of 12 elements (Ag, Al, As, B, Co, Cr, Cu, Fe, Ni, Pb, Se, and Zn) than the wood-growing mushrooms. An opposite relation was observed for $\mathrm{Au}, \mathrm{Ba}$, and Sr. Insignificant differences were found in the 11 remaining elements $(\mathrm{Bi}, \mathrm{Cd}, \mathrm{Ga}, \mathrm{Ge}, \mathrm{In}, \mathrm{Li}$, $\mathrm{Mn}, \mathrm{Re}, \mathrm{Sb}, \mathrm{Te}$, and Tl). Nevertheless, it should be borne in mind that some mean contents are distorted by outlying values, e.g., of As in M. procera (4.14 $\pm 1.33 \mathrm{mg} \mathrm{kg}^{-1}$ d.m.) or Fe in Suillus luteus $\left(315 \pm 31.4 \mathrm{mg} \mathrm{kg}^{-1}\right.$ d.m.). It is not possible to compare the results with the literature data because of a lack of information on the comparison of both the groups.

Based on a variance analysis at $\alpha=0.05$, separately for wood-growing species and aboveground mushroom species, it was stated that similarities and differences between them were diverse. The detailed Tukey test made it possible to select significantly different mushroom species as regards their abilities to accumulate particular elements inside the particular groups (Table 3).

No significant differences between the ability of mushroom species to accumulate germanium were observed in either of the groups. For most of the tested elements $(\mathrm{Ag}, \mathrm{Al}, \mathrm{As}, \mathrm{Au}$, $\mathrm{B}, \mathrm{Ba}, \mathrm{Cd}, \mathrm{Cr}, \mathrm{Cu}, \mathrm{Fe}, \mathrm{Ga}$, In, Li, Mn, Ni, Pb, Sb, Se, Sr, Te, $\mathrm{Tl}$, and $\mathrm{Zn})$, significant differences $(\alpha=0.01)$ in the accumulation capacities in both the groups (wood-growing and aboveground mushroom species) were observed. Accumulation of $\mathrm{Bi}$ and $\mathrm{Co}$ was only diverse within the wood-growing species, while Re accumulation in the 


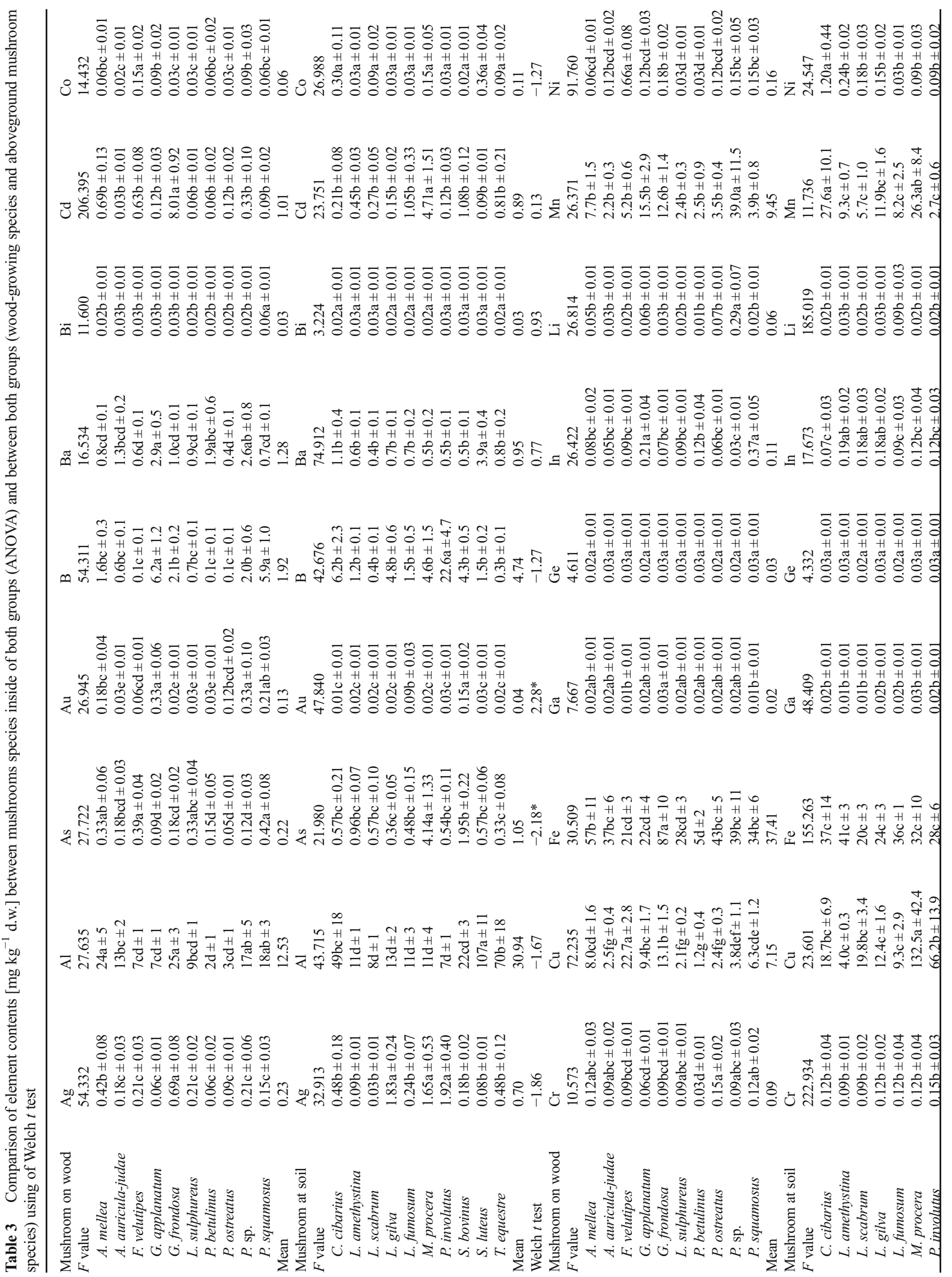




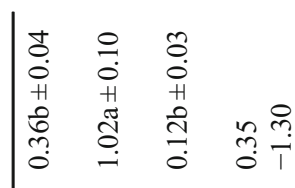



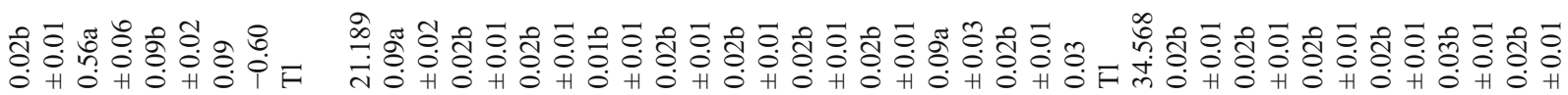

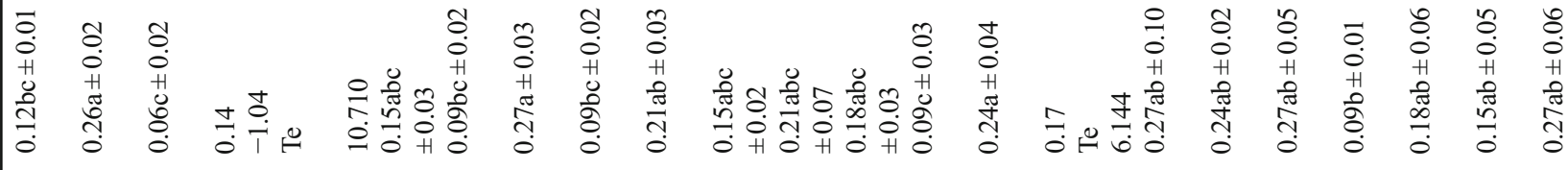

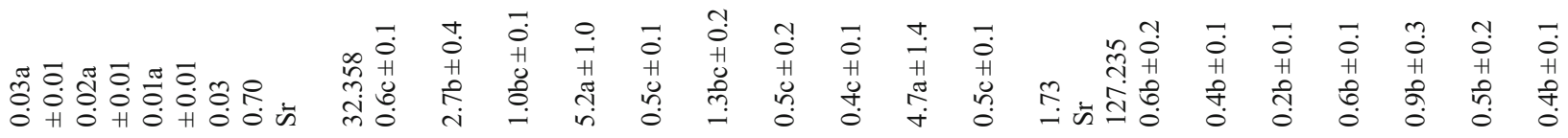

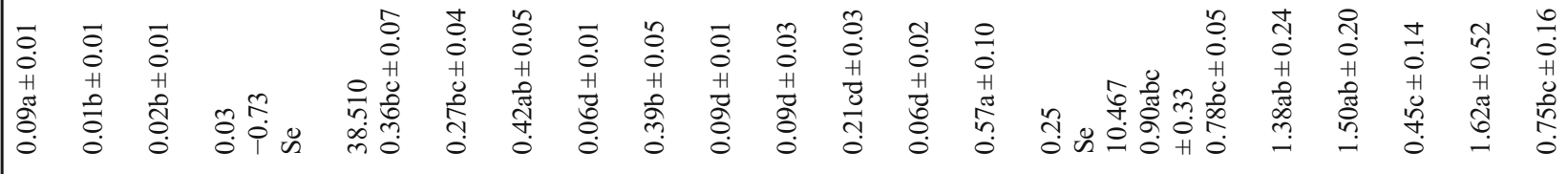



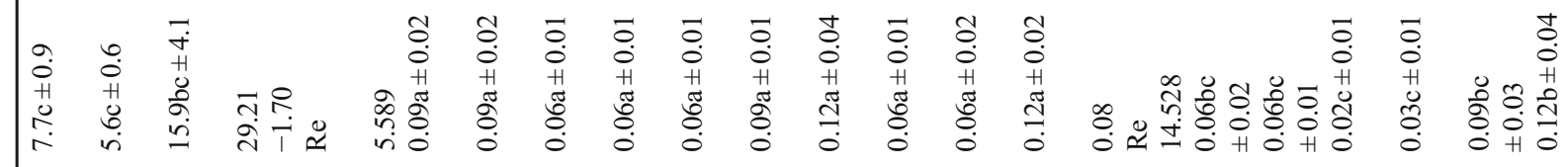

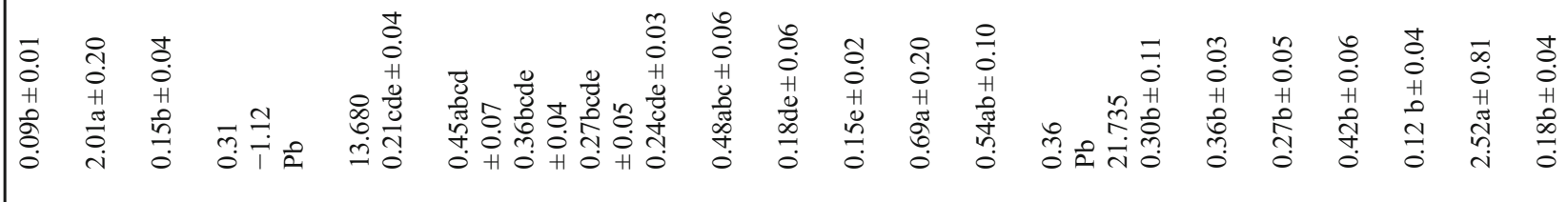

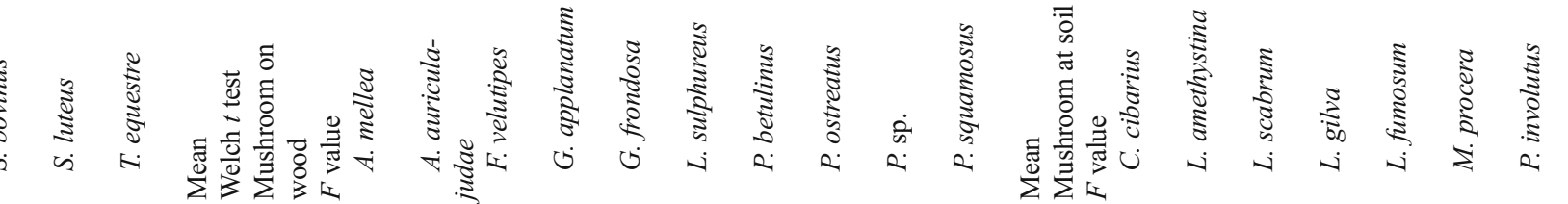


aboveground mushroom species only. When we compare both the groups of mushrooms, significant differences in $\mathrm{As}, \mathrm{Au}$ $(\alpha=0.05)$, and $\mathrm{Se}(\alpha=0.01)$ accumulation were revealed between the groups on the basis of the Welch Two-Sample $t$ test.

Literature data on trace elements for most of the tested wood-growing species are very limited, dealing preferably with Armillaria mellea, Flammulina velutipes, Pleurotus ostreatus and sporadically with Laetiporus sulphureus (Durkan et al. 2011; Gramss and Voigt 2013; Huang et al. 2015; Kaya and Bag 2010; Sarikurkcu et al. 2012; Severoglu et al. 2013; Zeng et al. 2012; Zhu et al. 2011). Moreover, the reported trace elements are considerably limited when compared to the present work. Overall, the literature data are comparable with our results only for $\mathrm{Zn}$, while for numerous elements ( $\mathrm{Al}, \mathrm{As}, \mathrm{B}, \mathrm{Co}, \mathrm{Cr}, \mathrm{Cu}, \mathrm{Fe}, \mathrm{Mn}, \mathrm{Ni}$, and $\mathrm{Pb}$ ) the reported levels are considerably higher, often by 1 order of magnitude. Cadmium contents fluctuated. Literature information on bioconcentration factors $(\mathrm{BCF})$, the ratio of metal content in a mushroom fruit body to the content in wood substrate (both in $\mathrm{mg} \mathrm{kg}^{-1}$ d.m.), is virtually lacking.

The mean contents of most individual elements in the group of aboveground species can be compared with extensive available data, particularly those collated in the review of Kalač (2010). In general, similar contents of As, B, Cd, Cu, $\mathrm{Fe}, \mathrm{Ga}, \mathrm{Mn}, \mathrm{Ni}, \mathrm{Sb}, \mathrm{Sr}$, and $\mathrm{Zn}$ were determined in comparison with the contents reported in fruit bodies of numerous mushroom species collected from unpolluted sites. The levels of $\mathrm{Ag}, \mathrm{Al}, \mathrm{Ba}, \mathrm{Co}, \mathrm{Cr}, \mathrm{Pb}, \mathrm{Se}$, and $\mathrm{Tl}$ were lower than usually reported in the literature data, while the opposite relation was observed only for $\mathrm{Au}$ and $\mathrm{Li}$. Literature data for $\mathrm{Bi}, \mathrm{Ge}, \mathrm{In}, \mathrm{Re}$, and Te are still insufficient.

Cuny et al. (2001) reported increased contents of cadmium, lead, and zinc in fruit bodies of several mushroom species growing along a French motorway as compared with the usual level for the same species collected from unpolluted sites. No similar situation was observed within the data of Table 3. This also deals with $\mathrm{Pb}$, which has formerly contaminated areas adjacent to heavily frequented roads from leaded petrol. Leaded petrol has not been used in Poland since the end of 2004.

For a graphical presentation of the obtained results and relationships between tested mushroom species growing on wood and in soil, a PCA was performed (Fig. 2). The analyses were performed for aboveground and woodgrowing mushroom species separately and the obtained results allowed similarities and differences in element accumulation to be determined in the studied mushroom species.

In mushrooms growing on wood (Fig. 2a), PCA analysis explained $46.86 \%$ of total variability of mushrooms to the observed element accumulation. Obtained results suggested that accumulation of $\mathrm{Ag}, \mathrm{Al}, \mathrm{Cd}$, and $\mathrm{Fe}$ was independent of As, Ge, Se, and Te as well as Li and Mn. Simultaneously, 
Fig. 2 PCA analysis for tested wood-growing species (a), aboveground mushroom species (b), and for both groups of mushrooms (c)
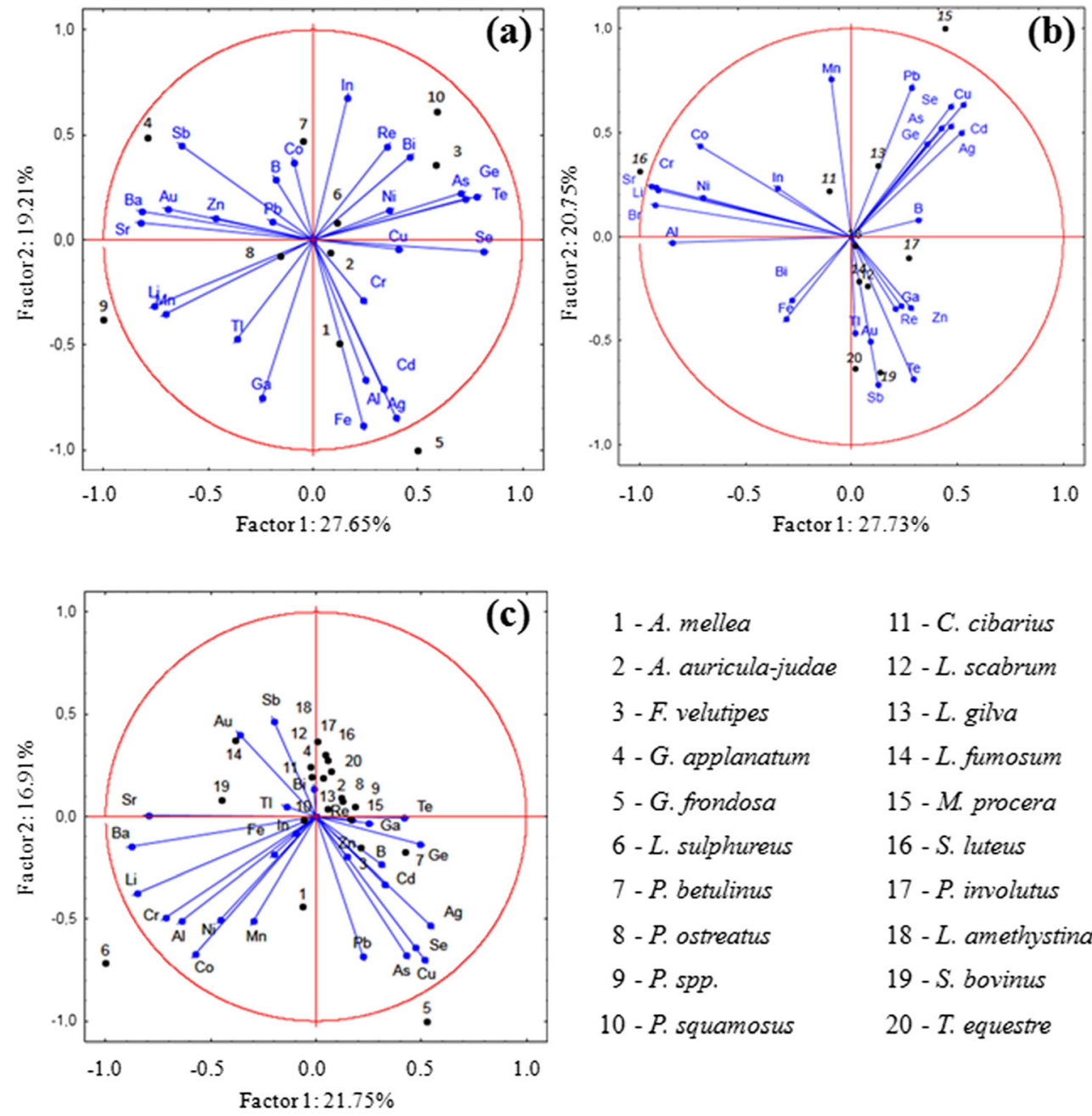

1 - A. mellea

2 - A. auricula-judae

11 - C. cibarius

3 - F. velutipes

4 - G. applanatum

5 - G. frondosa

6 - L. sulphureus

7 - P. betulinus

8 - P. ostreatus

9 - P. spp.

10 - P. squamosus
12 - L. scabrum

13 - L. gilva

14 - L. fumosum

15 - M. procera

16 - S. luteus

$17-P$. involutus

18 - L. amethystina

19 - S. bovinus

20 - T. equestre some groups of elements predominantly influenced element accumulation in individual mushroom species. In woodgrowing species, the following relationships were observed: Polyporus squamosus and Flammulina velutipes in relation to $\mathrm{Bi}, \mathrm{In}$, and $\mathrm{Re}$ and also $\mathrm{As}, \mathrm{Ge}, \mathrm{Te}$, and Se; Ganoderma applanatum - $\mathrm{Au}, \mathrm{Ba}$, and $\mathrm{Sr}$ as well as $\mathrm{Sb}$; Pleurotus spp.$\mathrm{Li}$ and $\mathrm{Mn}$; Grifola frondosa-Ag, Al, Cd, and Fe (Fig. 2a).

In mushrooms growing in soil (Fig. 2b), two principal components explained $48.48 \%$ of total variability. Accumulation of Au, Ga, Re, Sb, Te, Tl, and Zn was independent of Ag, As, $\mathrm{Cd}, \mathrm{Cu}, \mathrm{Ge}, \mathrm{Pb}$, and $\mathrm{Se}$. Additionally, accumulation of the last group of elements was independent of $\mathrm{Al}, \mathrm{Ba}, \mathrm{Co}, \mathrm{Cr}, \mathrm{Li}, \mathrm{Ni}$, and $\mathrm{Sr}$. In the aboveground species, the following relationships were stated: Macrolepiota procera-As, $\mathrm{Ag}, \mathrm{Cd}, \mathrm{Cu}$, $\mathrm{Ge}, \mathrm{Pb}$, and $\mathrm{Se}$; Suillus luteus-Al, $\mathrm{Ba}, \mathrm{Co}, \mathrm{Cr}, \mathrm{Li}, \mathrm{Ni}$, and $\mathrm{Sr}$; Suillus bovinus and Tricholoma equestre- $\mathrm{Au}, \mathrm{Ga}, \mathrm{Re}, \mathrm{Te}$, Tl, Sb, and Zn (Fig. 2b).

In the file of all the analyzed mushrooms and elements (Fig. 2c), two principal components explained 38.66\% of total variability. Accumulation of $\mathrm{Ag}, \mathrm{As}, \mathrm{Cu}, \mathrm{Pb}$, and $\mathrm{Se}$ was independent of $\mathrm{Al}, \mathrm{Co}, \mathrm{Cr}, \mathrm{Li}, \mathrm{Ni}$, and $\mathrm{Mn}$. Based on all
20 tested mushroom species and all 26 analyzed elements, the following relationships within both the groups were as follows: Grifola frondosa-Ag, $\mathrm{As}, \mathrm{Cu}, \mathrm{Pb}$, and $\mathrm{Se}$; Laetiporus sulphureus-Al, $\mathrm{Co}, \mathrm{Cr}, \mathrm{Li}, \mathrm{Ni}$, and $\mathrm{Mn}$.

\section{Content of elements in wood-growing species}

Varying contents of elements were observed within the group of wood-growing species. As may be seen in the results from Table 3, each of the four species displayed the highest level of five elements: Ganoderma applanatum (Au, B, Ba, Sb, and $\mathrm{Sr}$ ), Grifola frondosa (Ag, Al, Cd, Fe, and Ga), Pleurotus spp. (Au, Li, Mn, $\mathrm{Pb}$, and $\mathrm{Tl}$ ), and Polyporus squamosus (As, Bi, In, Re, and Se). Armillaria mellea displayed a high content of $\mathrm{Al}\left(24 \pm 5 \mathrm{mg} \mathrm{kg}^{-1}\right.$ d.m.); its mean $\mathrm{Tl}$ level was comparable with Pleurotus spp. (0.09 $\mathrm{mg} \mathrm{kg}^{-1}$ d.m.). F. velutipes contained elevated levels of $\mathrm{As}, \mathrm{Co}, \mathrm{Cu}$, and $\mathrm{Ni}(0.39$ $\pm 0.04,0.15 \pm 0.02,22.7 \pm 2.8$, and $0.66 \pm 0.08 \mathrm{mg} \mathrm{kg}^{-1}$ d.m., respectively). The highest content of $\mathrm{Cr}$ and $\mathrm{Zn}$ was observed in fruit bodies of Pleurotus ostreatus 
Fig. 3 Correlation between tested wood-growing species with regard to the accumulation of all analyzed elements jointly (Heatmap) with presentation of a hierarchical tree plot to show the groups of mushrooms characterized by a high similarity to all element accumulation

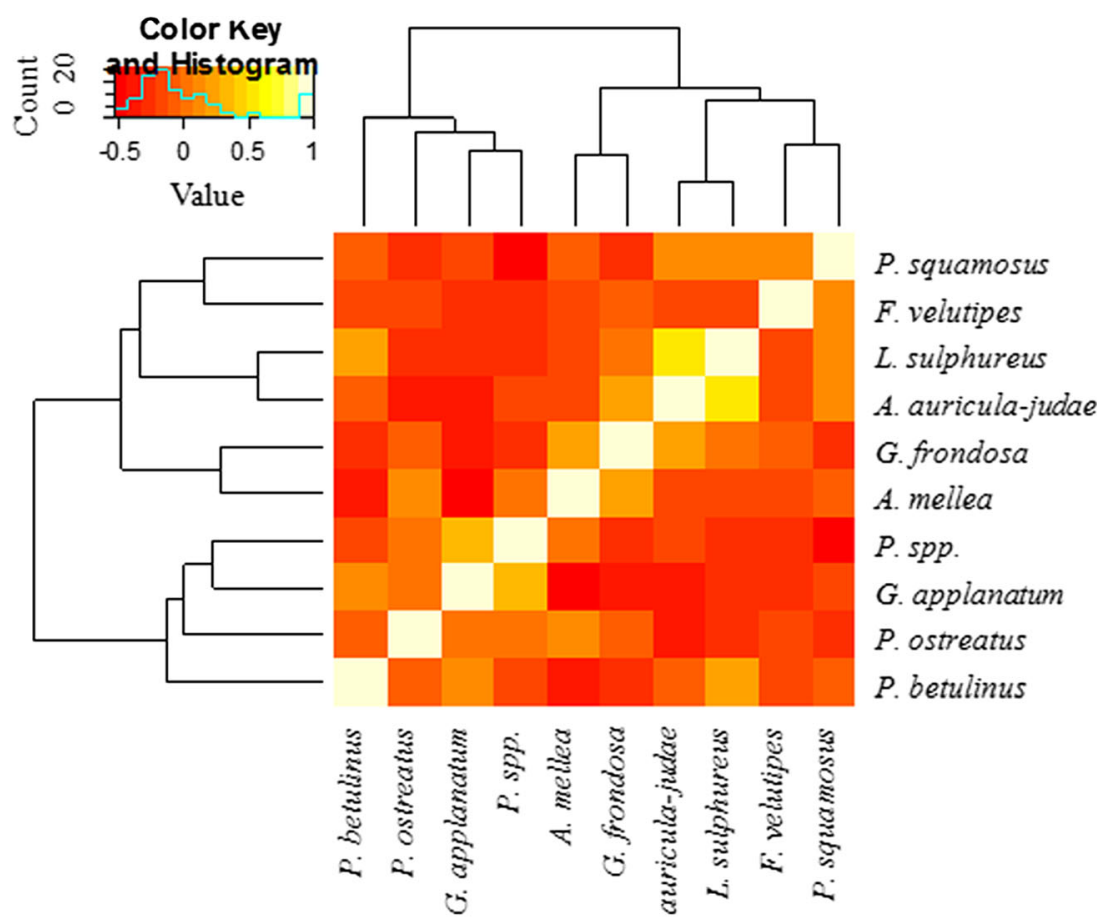

Cluster Dendrogram

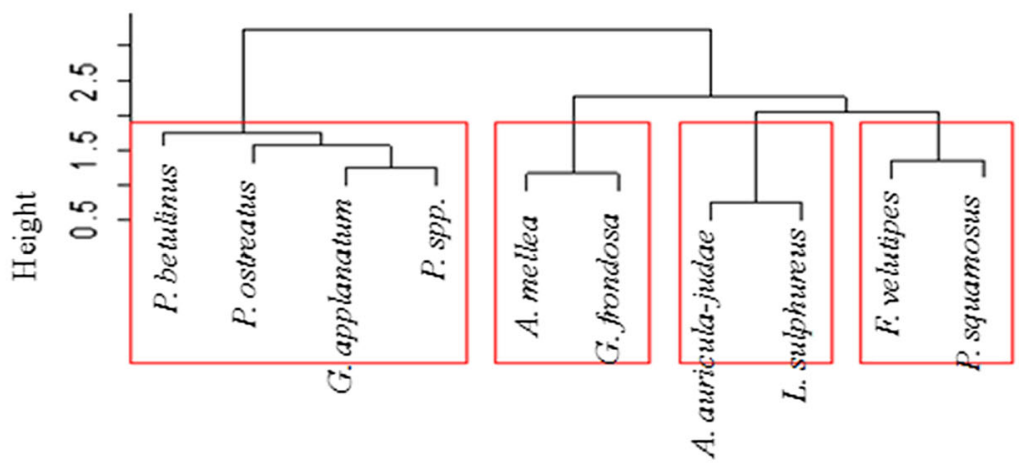

hclust (*, "ward.D2") $\left(0.15 \pm 0.02\right.$ and $90 \pm 11.2 \mathrm{mg} \mathrm{kg}^{-1}$ d.m., respectively). The greatest of all the significant differences among the tested species were observed for $\mathrm{Pb}, \mathrm{Cr}$, and $\mathrm{Cu}$, while no differences were found for Ge and Re. Information on trace elements in wood-growing species is very fragmentary in the literature.

Based on the obtained results, the correlation between the tested mushroom species growing on wood as regards the accumulation of all analyzed elements jointly (Heatmap) reveals similarities and differences between mushroom species (Fig. 3).

A cluster dendrogram was also performed so as to distinguish which mushroom groups accumulate elements in a similar way. Four diverse groups of mushrooms were indicated: (i) Piptoporus betulinus, Pleurotus ostreatus,
Ganoderma applanatum, and Pleurotus spp., (ii) Armillaria mellea and Grifola frondosa; (iii) Auricularia auricula-judae and Laetiporus sulphureus; and (iv) F. velutipes and Polyporus squamosus. On the other hand, in order to show the similarities between elements, which were accumulated in the same way by all wood-growing species, another Heatmap analysis was performed (Fig. 4).

In this case, four groups of elements were indicated: (i) $\mathrm{Au}$, $\mathrm{Ba}, \mathrm{Li}, \mathrm{Ga}, \mathrm{Mn}, \mathrm{Pb}, \mathrm{Sb}, \mathrm{Sr}, \mathrm{Tl}$, and $\mathrm{Zn}$; (ii) $\mathrm{Al}, \mathrm{Ag}, \mathrm{Cd}, \mathrm{Cr}$, and $\mathrm{Fe}$; (iii) B, Bi, In, and Re; (iv) As, $\mathrm{Co}, \mathrm{Cu}, \mathrm{Ge}, \mathrm{Ni}, \mathrm{Se}$, and Te.

\section{Content of elements in aboveground mushroom species}

The tested mushroom species were diverse in terms of their ability to accumulate particular elements from soil 
Fig. 4 Correlation between analyzed elements as regards their accumulation in all woodgrowing species (Heatmap) with presentation of a hierarchical tree plot to show the groups of similarly accumulated elements
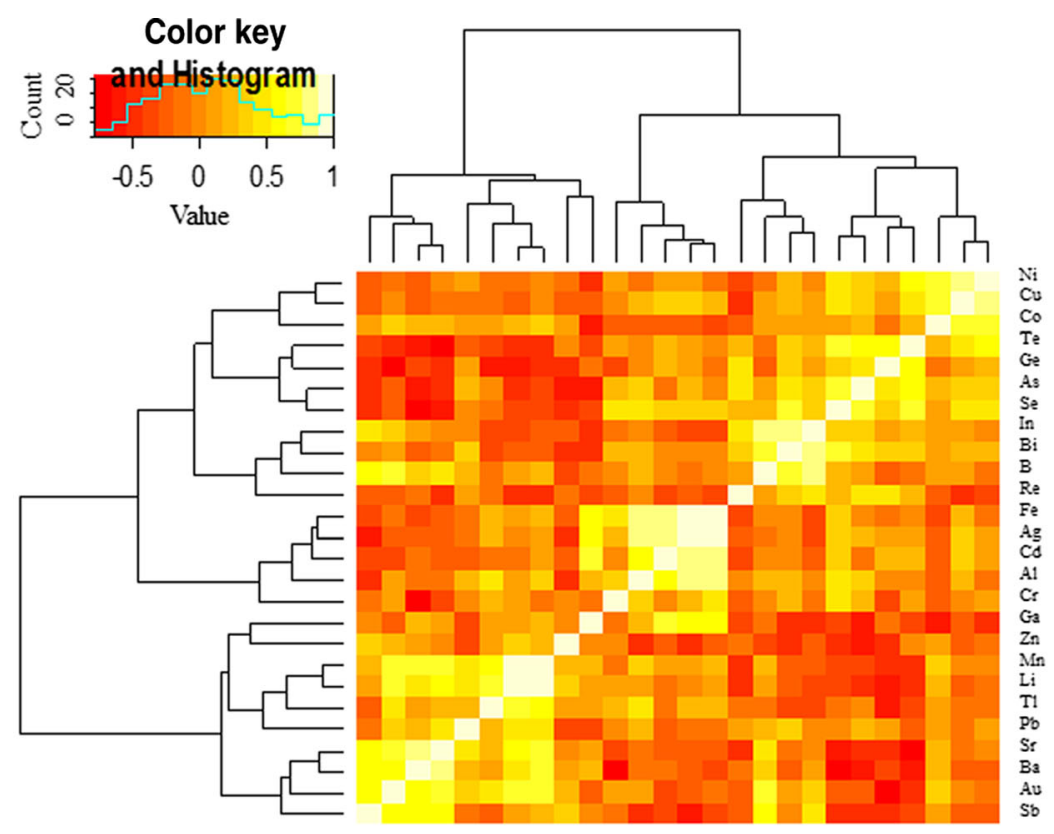

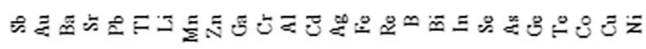

\section{Cluster Dendrogram}

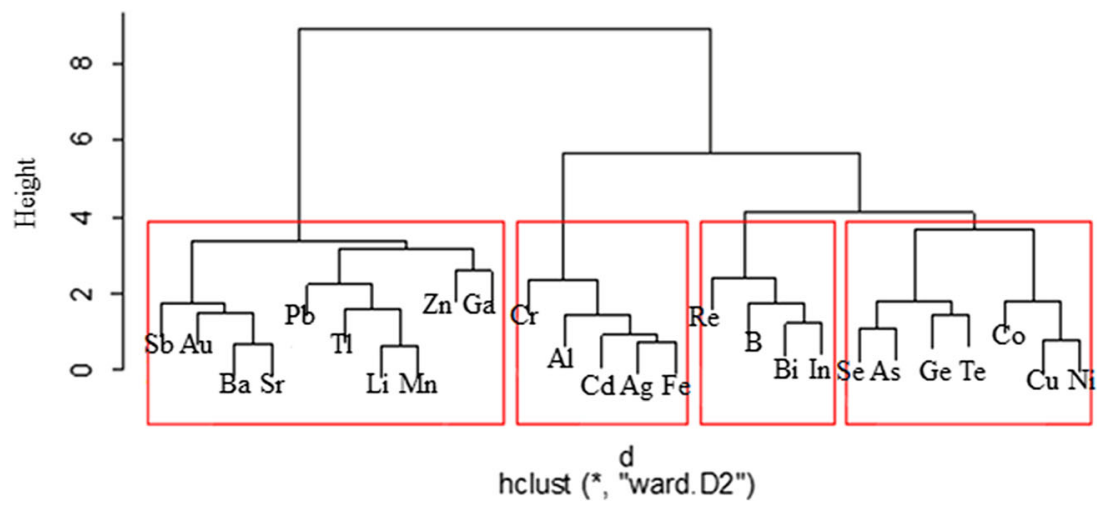

(Table 3). Some species were able to selectively accumulate particular elements and limit the accumulation of others. Cantharellus cibarius was found to accumulate the highest content of $\mathrm{Mn}$ and $\mathrm{Ni}(27.6 \pm 10.1$ and 1.20 $\pm 0.44 \mathrm{mg} \mathrm{kg}^{-1} \mathrm{~d}$.m., respectively), while $M$. procera fruit bodies contained the highest levels of $\mathrm{As}, \mathrm{Cd}, \mathrm{Cu}, \mathrm{Pb}$, and Se $(4.14 \pm 1.33,4.71 \pm 1.51,132.5 \pm 42.4,2.52 \pm 0.81$, and $1.62 \pm 0.52 \mathrm{mg} \mathrm{kg}^{-1}$ d.m., respectively). M. procera is known to be an accumulator of these elements (Kalač 2010). The highest content of Ag was observed in Lepista gilva, M. procera, and Paxillus involutus (1.83 $\pm 0.24,1.65 \pm 0.53$, and $1.92 \pm 0.40 \mathrm{mg} \mathrm{kg}^{-1} \mathrm{~d} . \mathrm{m}$., respectively). Paxillus involutus was the most effective boron accumulator $\left(22.6 \pm 4.7 \mathrm{mg} \mathrm{kg}^{-1}\right.$ d.m.) among mushroom species. For other elements, the highest content of $\mathrm{Al}, \mathrm{Ba}$, $\mathrm{Cr}, \mathrm{In}, \mathrm{Li}$, and $\mathrm{Sr}$ was observed in $\mathrm{S}$. luteus fruit bodies $(107 \pm 11,3.9 \pm 0.4,2.01 \pm 0.20,0.26 \pm 0.02,0.56 \pm 0.06$, and $4.4 \pm 0.4 \mathrm{mg} \mathrm{kg}^{-1} \mathrm{~d} . \mathrm{m}$., respectively), while As, Fe, $\mathrm{Ga}$, and $\mathrm{Te}$ in $S$. bovinus $(0.15 \pm 0.02,621 \pm 72,0.09$ \pm 0.01 , and $0.30 \pm 0.03 \mathrm{mg} \mathrm{kg}^{-1} \mathrm{~d} . \mathrm{m}$., respectively). The highest content of $\mathrm{Re}, \mathrm{Tl}$, and $\mathrm{Zn}$ was observed in T. equestre $(0.21 \pm 0.05,0.21 \pm 0.05$, and 186 $\pm 47 \mathrm{mg} \mathrm{kg}^{-1}$ d.m., respectively). In three elements, Bi, $\mathrm{Co}$, and $\mathrm{Ge}$, no significant differences were observed among the tested mushroom species.

Analysis of the Heatmap in order to compare the tested aboveground mushroom species as regards their abilities to accumulate all 26 elements pointed to the existence of four different mushroom groups (Fig. 5). The following mushroom species were included in the specified groups: (i) Leccinum scabrum and Laccaria amethystina; (ii) M. procera, Lepista gilva, and Paxillus involutus; (iii) C. cibarius and S. luteus; and (iv) T. equestre, Lyophyllum fumosum and S. bovinus. 
Fig. 5 Correlation between tested aboveground mushroom species with regard to the accumulation of all analyzed elements jointly (Heatmap) with presentation of a hierarchical tree plot to show the groups of mushrooms characterized by a high similarity to all element accumulation
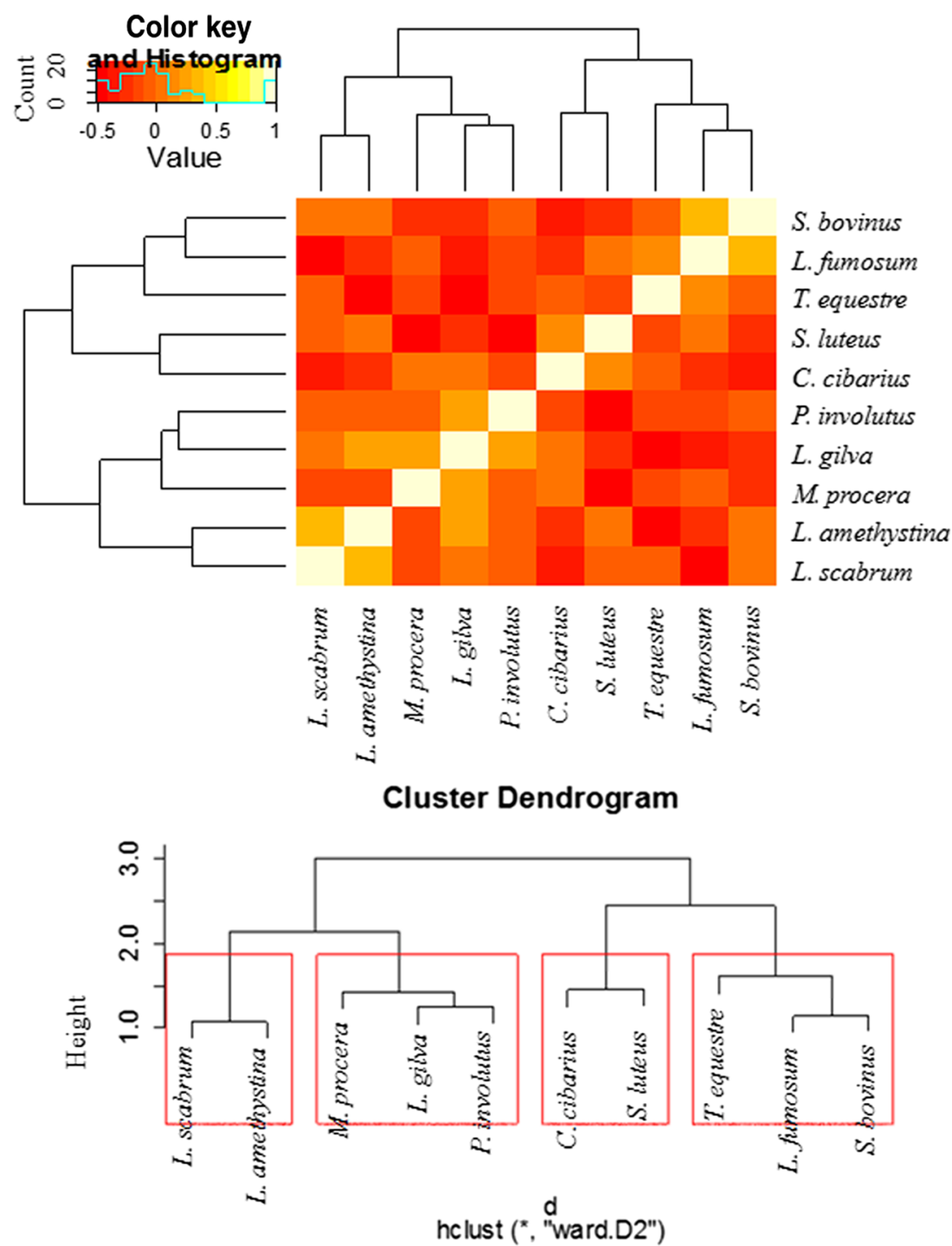

In the additional Heatmap analysis, the correlation between each of the analyzed elements considering their accumulation in all tested mushroom species growing in soil is presented below (Fig. 6). The data pointed to the existence of four variable groups of elements. The elements were accumulated within each of the groups by all mushroom species in the same or a similar way. Based on a hierarchical tree plot, the elements were classified into four groups: (i) $\mathrm{Al}, \mathrm{Ba}, \mathrm{Co}, \mathrm{Cr}, \mathrm{Li}, \mathrm{Ni}$, and $\mathrm{Sr}$; (ii) $\mathrm{Ag}, \mathrm{As}, \mathrm{B}, \mathrm{Cd}, \mathrm{Cu}, \mathrm{Ge}, \mathrm{Mn}, \mathrm{Pb}$, and $\mathrm{Se}$; (iii) $\mathrm{Re}, \mathrm{Sb}, \mathrm{Te}$, $\mathrm{Tl}$, and $\mathrm{Zn}$; and (iv) $\mathrm{Au}, \mathrm{Bi}, \mathrm{Fe}, \mathrm{Ga}$, and In.

To show the efficiency of the tested mushroom species to element uptake, the BCF values were calculated (Table 4).

BCF $>1$ affirmed that element accumulation took place in (was observed for) all 10 aboveground mushroom species in the case of $\mathrm{Cu}, \mathrm{Se}$, and $\mathrm{Zn}$. Moreover, the same observations were stated for C. cibarius (Ag, B), Laccaria amethystina (As), Lepista gilva (Ag, B), Lyophyllum fumosum $(\mathrm{Cd}), M$. procera ( $\mathrm{Ag}, \mathrm{As}, \mathrm{B}$, and $\mathrm{Cd}$ ), Paxillus involutus (Ag, B), S. bovinus (As, B, Cd, and $\mathrm{Ga}$ ), and T. equestre (Ag, $\mathrm{Cd}, \mathrm{Re}$, and $\mathrm{Tl})$. For the remaining elements in analyzed mushroom species, BCF values were lower than 1, which was related with their bioexclusion. Alonso et al. (2003) have also analyzed C. cibarius, Leccinum scabrum, M. procera, and T. equestre and calculated BCF values for $\mathrm{Cu}(3.30$, 2.94, 18.64, and 6.25, respectively) and $\mathrm{Zn}(5.63,4.96$, 3.45 , and 6.17 , respectively). Their values were generally similar to those presented in this paper $(5.74,6.08,40.63$, and 4.88, respectively for $\mathrm{Cu}$ and $6.97,5.97,4.64$, and 12.06 , respectively for $\mathrm{Zn}$ ). Additionally, presented data confirmed observations reported by Gucia et al. (2012a), who pointed out the bioexclusion of $\mathrm{Al}, \mathrm{Ba}, \mathrm{Co}, \mathrm{Cr}, \mathrm{Fe}$, $\mathrm{Ni}$, and $\mathrm{Sr}$ and the effective accumulation of $\mathrm{Ag}, \mathrm{Cd}, \mathrm{Cu}$, and $\mathrm{Zn}$ in $M$. procera fruiting bodies. 
Fig. 6 Correlation between analyzed elements as regards their accumulation in all aboveground mushroom species (Heatmap) with presentation of a hierarchical tree plot to show the groups of similarly accumulated elements
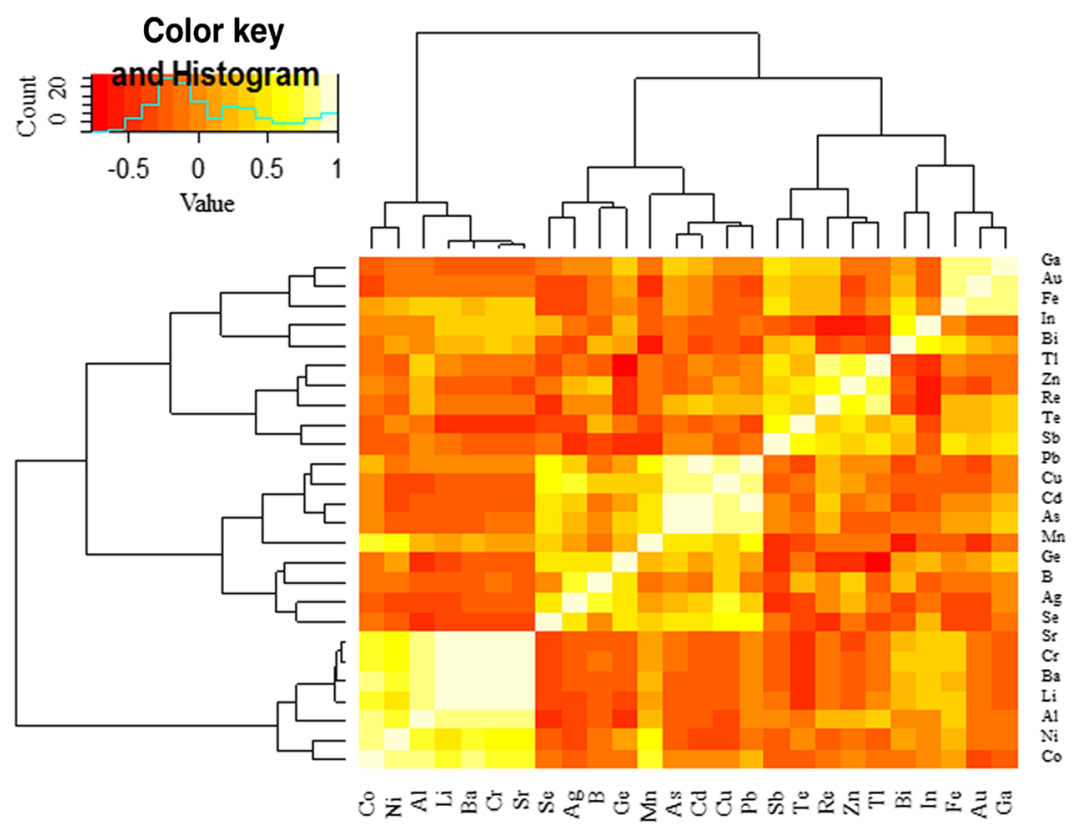

Cluster Dendrogram

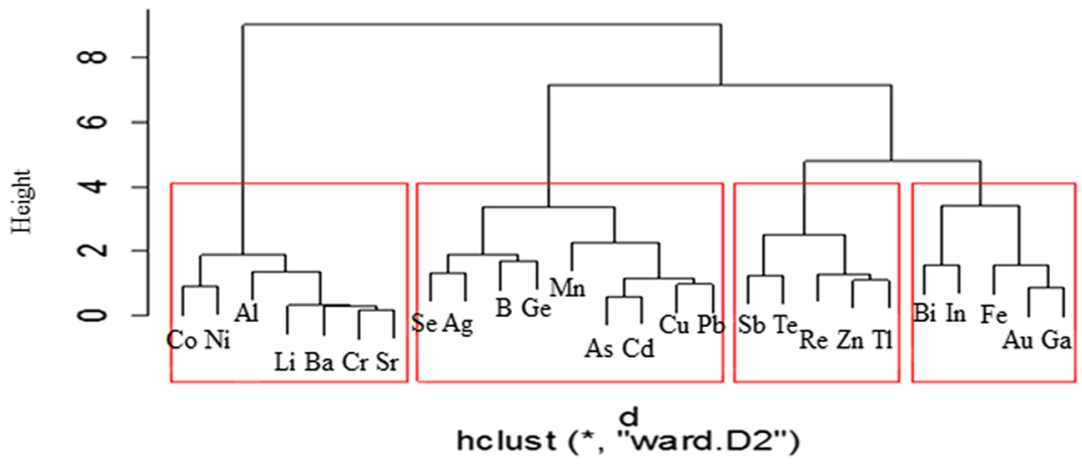

\section{Intake of mushrooms and the risk for humans}

A recent recommendation of the WHO sets a provisional tolerable monthly intake (PTMI) for cadmium at $0.025 \mathrm{mg} \mathrm{kg}^{-1}$ bodyweight for an adult. For an individual weighing $60 \mathrm{~kg}$, the value is $1.5 \mathrm{mg}$ per month. An average single serving is $300 \mathrm{~g}$ of fresh mushrooms, i.e., about $30 \mathrm{~g}$ of d.m., as a $10 \%$ level is used for calculations with an unknown factual d.m. level. A less probable scenario is a serving of $500 \mathrm{~g}$. In Grifola frondosa, the species with the highest mean $\mathrm{Cd}$ content of $8.01 \mathrm{mg} \mathrm{kg}^{-1}$ d.m., the intake would be 0.24 and $0.40 \mathrm{mg}$ from lower and higher model serving, respectively. The respective intakes from $M$. procera, with a mean content in the present work of $4.71 \mathrm{mg} \mathrm{Cd}$ per $\mathrm{kg} \mathrm{d.m.,} \mathrm{the} \mathrm{respective} \mathrm{intake} \mathrm{would} \mathrm{be}$ 0.14 and $0.24 \mathrm{mg}$.

The WHO determines the maximum daily intake of lead at $0.0012 \mathrm{mg} \mathrm{kg}^{-1}$ bodyweight, i.e., $0.072 \mathrm{mg}$ for an adult weighing $60 \mathrm{~kg}$. The maximum determined $\mathrm{Pb}$ content of
$2.52 \mathrm{mg} \mathrm{kg}^{-1}$ d.m. in $M$. procera would thus deliver a dose of 0.076 and $0.126 \mathrm{mg}$ from servings of 300 and $500 \mathrm{~g}$ of the fresh $M$. procera, respectively.

Considering the above calculations, a potential health risk would arise from the consumption of a single serving of species accumulating $\mathrm{Pb}$. For $\mathrm{Cd}$, the risk increases under repeated consumption of accumulating species during a short period, which is probable as the wild mushroom harvest takes place largely over several weeks during the fall. Moreover, these calculations are simplified because mushrooms are not the sole dietary source of detrimental metals. On the other hand, one should consider the bioavailability of $\mathrm{Cd}$ and $\mathrm{Pb}$ from investigated mushrooms for humans. Unfortunately, information on species of trace elements in mushrooms, including elements with a potential health risk, has been very limited until now (Kalač 2010). As demonstrated, cooking methods such as boiling or microwaving with water can significantly decrease the content of toxic metals in 
Table 4 Bioconcentration factor (BCF) values for aboveground mushroom species

\begin{tabular}{|c|c|c|c|c|c|c|c|c|c|c|}
\hline Element & C. cibarius & L. amethystina & L. scabrum & L. gilva & L. fumosum & M. procera & P. involutus & S. bovinus & S. luteus & T. equestre \\
\hline $\mathrm{Ag}$ & 1.66 & 0.31 & 0.10 & 6.31 & 0.83 & 5.69 & 6.62 & 0.62 & 0.28 & 1.66 \\
\hline $\mathrm{Al}$ & 0.02 & 0.00 & 0.00 & 0.01 & 0.00 & 0.00 & 0.00 & 0.01 & 0.05 & 0.03 \\
\hline As & 0.77 & 1.30 & 0.77 & 0.49 & 0.65 & 5.59 & 0.73 & 2.64 & 0.77 & 0.45 \\
\hline $\mathrm{Au}$ & 0.01 & 0.02 & 0.02 & 0.02 & 0.09 & 0.02 & 0.03 & 0.15 & 0.03 & 0.02 \\
\hline $\mathrm{B}$ & 2.99 & 0.59 & 0.17 & 2.30 & 0.72 & 2.20 & 10.81 & 2.04 & 0.72 & 0.16 \\
\hline $\mathrm{Ba}$ & 0.05 & 0.03 & 0.02 & 0.03 & 0.03 & 0.02 & 0.02 & 0.02 & 0.17 & 0.03 \\
\hline $\mathrm{Bi}$ & 0.05 & 0.08 & 0.08 & 0.05 & 0.05 & 0.05 & 0.08 & 0.08 & 0.08 & 0.05 \\
\hline $\mathrm{Cd}$ & 0.45 & 0.96 & 0.57 & 0.32 & 2.23 & 10.02 & 0.26 & 2.30 & 0.19 & 1.72 \\
\hline Co & 0.18 & 0.02 & 0.05 & 0.02 & 0.02 & 0.09 & 0.02 & 0.01 & 0.22 & 0.05 \\
\hline $\mathrm{Cr}$ & 0.03 & 0.02 & 0.02 & 0.03 & 0.03 & 0.03 & 0.04 & 0.02 & 0.49 & 0.04 \\
\hline $\mathrm{Cu}$ & 5.74 & 1.21 & 6.08 & 3.81 & 2.85 & 40.63 & 20.31 & 2.36 & 1.72 & 4.88 \\
\hline $\mathrm{Fe}$ & 0.01 & 0.01 & 0.01 & 0.01 & 0.01 & 0.01 & 0.01 & 0.19 & 0.10 & 0.03 \\
\hline $\mathrm{Ga}$ & 0.67 & 0.33 & 0.33 & 0.67 & 0.67 & 1.00 & 0.67 & 3.00 & 0.33 & 0.67 \\
\hline $\mathrm{Ge}$ & 0.60 & 0.60 & 0.40 & 0.60 & 0.40 & 0.60 & 0.60 & 0.60 & 0.40 & 0.20 \\
\hline In & 0.05 & 0.17 & 0.13 & 0.13 & 0.06 & 0.09 & 0.09 & 0.09 & 0.15 & 0.04 \\
\hline $\mathrm{Li}$ & 0.03 & 0.04 & 0.03 & 0.04 & 0.12 & 0.03 & 0.03 & 0.03 & 0.73 & 0.12 \\
\hline $\mathrm{Mn}$ & 0.25 & 0.08 & 0.05 & 0.11 & 0.07 & 0.24 & 0.02 & 0.04 & 0.14 & 0.08 \\
\hline $\mathrm{Ni}$ & 0.43 & 0.09 & 0.06 & 0.05 & 0.01 & 0.03 & 0.03 & 0.13 & 0.36 & 0.04 \\
\hline $\mathrm{Pt}$ & 0.04 & 0.05 & 0.03 & 0.05 & 0.02 & 0.32 & 0.02 & 0.02 & 0.07 & 0.08 \\
\hline $\mathrm{Re}$ & 0.29 & 0.29 & 0.10 & 0.14 & 0.43 & 0.57 & 0.43 & 0.57 & 0.29 & 1.00 \\
\hline $\mathrm{Sb}$ & 0.11 & 0.16 & 0.47 & 0.11 & 0.16 & 0.16 & 0.16 & 0.47 & 0.16 & 0.47 \\
\hline $\mathrm{Se}$ & 6.92 & 6.00 & 10.62 & 11.54 & 3.46 & 12.46 & 5.77 & 5.54 & 4.15 & 3.46 \\
\hline $\mathrm{Sr}$ & 0.06 & 0.05 & 0.03 & 0.06 & 0.10 & 0.05 & 0.04 & 0.04 & 0.50 & 0.06 \\
\hline $\mathrm{Te}$ & 0.44 & 0.39 & 0.44 & 0.15 & 0.29 & 0.24 & 0.44 & 0.48 & 0.19 & 0.44 \\
\hline $\mathrm{Tl}$ & 0.15 & 0.15 & 0.15 & 0.15 & 0.23 & 0.15 & 0.15 & 0.15 & 0.15 & 1.62 \\
\hline $\mathrm{Zn}$ & 6.97 & 2.26 & 5.97 & 3.42 & 2.74 & 4.64 & 8.81 & 3.47 & 2.76 & 12.06 \\
\hline
\end{tabular}

mushrooms (Svoboda et al. 2002) and moreover, lower their bioaccessibility in the human gastrointestinal tract (Sun et al. 2012). Therefore, the conclusive health risks cannot be fully assessed through investigations of total metal content in the fruiting bodies of mushrooms.

\section{Conclusions}

Some 400 original papers dealing with trace elements in mushroom fruit bodies have been published to date. Several elements or even only one (e.g., $\mathrm{Hg}$ or $\mathrm{Se}$ ) was mostly determined. Recent ICP instruments enable researchers to quantify many elements including those so far very limited in terms of both data on content and knowledge of their biological roles. Furthermore, statistical methods such as PCA and HCA help to reveal new relationships within multielemental files. The adaptation of such tools and methods can be advantageous for the resolution of natural relations dealing with trace metal bioaccumulation/bioexclusion in various mushroom species. This article counts as one of the initial studies set within the multielemental research conception of mushrooms.

Acknowledgments This work was supported by the Polish Ministry of Science and Higher Education under Grant N N305 372538.

Open Access This article is distributed under the terms of the Creative Commons Attribution 4.0 International License (http:// creativecommons.org/licenses/by/4.0/), which permits unrestricted use, distribution, and reproduction in any medium, provided you give appropriate credit to the original author(s) and the source, provide a link to the Creative Commons license, and indicate if changes were made.

\section{References}

Alonso J, Garcia MA, Pérez-López M, Melgar MJ (2003) The concentrations and bioconcentration factors of copper and zinc in edible 
mushrooms. Arch Environ Contam Toxicol 44:180-188. doi:10. 1007/s00244-002-2051-0

Árvay J, Tomáš J, Hauptvogl M, Kopernická M, Kováčik A, Bajčan D, Massányi P (2014) Contamination of wild-grown edible mushrooms by heavy metals in a former mercury-mining area. J Environ Sci Health B 49:815-827. doi:10.1080/03601234.2014.938550

Ayaz FA, Torun H, Colak A, Sesli E, Millson M, Glew RH (2011) Macroand microelement contents of fruiting bodies of wild-edible mushrooms growing in the east Black Sea region of Turkey. Food Nutr Sci 2:53-59. doi:10.4236/fns.2011.22007

Borovička J, Řanda Z (2007) Distribution of iron, cobalt, zinc and selenium in macrofungi. Mycol Prog 6:249-259. doi:10.1007/s11557007-0544-y

Breś W, Golcz A, Komosa A, Kozik E, Tyksiński W (2009) Żywienie roślin ogrodniczych. The breeding of garden plants. University of Life Sciences Publishing, Poznań [in Polish]

Chojnacka A, Jarzyńska G, Lewandowska M, Nnorom IC, Falandysz J (2013) Trace elements in Yellow-cracking Bolete [Xerocomus subtomentosus (L.) Quel.] collected at the same site over three years. Fresen Environ Bull 22:2707-2712

Chudzyński K, Jarzyńska G, Falandysz J (2013) Cadmium, lead and some other trace elements in Larch Bolete mushrooms (Suilllus grevillei) (Klotzch) Sing., collected from the same site over two years. Food Addit Contam B 6:249-253. doi:10.1080/19393210. 2013.807881

Cuny D, van Haluwyn C, Pesch R (2001) Biomonitoring of trace elements in air and soil compartments along the major motorway in France. Water Air Soil Poll 125:273-289. doi:10.1023/ A:1005278900969

Czępińska-Kamińska D, Biały K, Brożek S, Chojnicki J, Januszek K, Kowalkowski A, Krzyżanowski A, Okołowicz M, Sienkiewicz A, Skiba S, Wójcik J, Zielony R (2000) Klasyfikacja gleb leśnych Polski. CILP Warszawa 1-123 [in Polish]

Durkan N, Ugulu I, Unver MC, Dogan Y, Baslar S (2011) Concentrations of trace elements aluminum, boron, cobalt and tin in various wild edible mushroom species from Buyuk Menderes River Basin of Turkey by ICP-OES. Trace Elem Electroly 28:242-248. doi:10. 5414/TEX01198

Environmental Protection Agency (2015) Inventory of U.S. greenhouse gas emissions and sinks: 1990-2013. Washington.

Falandysz J, Borovička J (2013) Macro and trace mineral constituents and radionuclides in mushrooms: health benefit and risks. Appl Microbiol Biotechnol 97:477-501. doi:10.1007/s00253-012-4552-8

Falandysz J, Lipka K, Mazur A (2007) Mercury and its bioconcentration factors in fly agaric (Amanita muscaria) from spatially distant sites in Poland. J Environ Sci Health A 42:1625-1630. doi:10.1080/ 10934520701517879

Falandysz J, Widzicka E, Kojta AK, Jarzyńska G, Drewnowska M, Dryżałowska A, Danisiewicz-Czupryńska D, Lenz E, Nnorom IC (2012) Mercury in common chanterelles mushrooms: Cantharellus spp. update. Food Chem 133:842-850. doi:10.1016/j.foodchem. 2012.01.102

GDDKiA 2005. Generalny pomiar ruchu w 2005 roku (General traffic measurement in 2005). Available from: http://www.gddkia.gov.pl/ userfiles/articles/g/GENERALNY_POMIAR_RUCHU_2005/0.1. 2.2_SDR_w_pkt_pomiarowych_w_2005_roku.pdf

GDDKiA 2010. Generalny pomiar ruchu w 2010 roku. (General traffic measurement in 2010). Available from: http://www.gddkia.gov.pl/ userfiles/articles/g/GENERALNY_POMIAR_RUCHU_2010/0.1. 1.4 SDR w pkt pomiarowych_w_2010 roku.pdf

Gramss G, Voigt K-D (2013) Clues for regulatory processes in fungal uptake and transfer of minerals to the basidiospore. Biol Trace Elem Res 154:140-149. doi:10.1007/s12011-013-9719-3

Gucia M, Jarzyńska G, Rafał E, Roszak M, Kojta AK, Osiej I, Falandysz J (2012a) Multivariate analysis of mineral constituents of edible Parasol Mushroom (Macrolepiota procera) and soils beneath fruiting bodies collected from Northern Poland. Environ Sci Pollut Res 19:416-431. doi:10.1007/s11356-011-0574-5

Gucia M, Jarzyńska G, Kojta AK, Falandysz J (2012b) Temporal variability in 20 chemical elements content of Parasol Mushroom (Macrolepiota procera) collected from two sites over a few years. J Environ Sci Health B 47:81-88. doi:10.1080/03601234.2012. 611433

Huang Q, Jia Y, Wan Y, Li H, Jiang R (2015) Market survey and risk assessment for trace metals in edible fungi and the substrate role in accumulation of heavy metals. J Food Sci 80:1612-1618. doi:10. 1111/1750-3841.12923

ISO 11271:2002 Jakość gleby. Oznaczanie potencjału redox. Metoda polowa. (Soil quality. Determination of redox potential. Field method.) [in Polish]

IUSS. World Reference Base for Soil Resources 2014, update 2015. International soil classification system for naming soils and creating legends for soil maps. World Soil Resources Reports No. 106. FAO, Rome.

Kalač P (2010) Trace element contents in European species of wild growing edible mushrooms: a review for the period 2000-2009. Food Chem 122:2-15. doi:10.1016/j.foodchem.2010.02.045

Kalač P, Svoboda L (2000) A review of trace element concentrations in edible mushrooms. Food Chem 69:273-281

Kaya A, Bag H (2010) Trace element contents of edible macrofungi growing in Adiayman, Turkey. Asian J Chem 22:1515-1521

Kojta AK, Jarzyńska G, Falandysz J (2012) Mineral composition and heavy metal accumulation capacity of Bay Bolete (Xerocomus badius) fruiting bodies collected near a former gold and copper mining area. J Geochem Explor 121:76-82. doi:10.1016/j.gexplo. 2012.08.004

Künzli N, Kaiser R, Medina S, Studnicka M, Chanel O, Filliger P, Herry M, Horak F Jr, Puybonnieux-Texier V, Quénel P, Schneider J, Seethaler R, Vergnaud J-C, Sommer H (2000) Public-health impact of outdoor and traffic-related air pollution: a European assessment. Lancet 356:795-801. doi:10.1016/S0140-6736(00)02653-2

Mleczek M, Siwulski M, Mikołajczak P, Gąsecka M, Rissmann I, Goliński P, Sobieralski K (2015a) Differences in Cu content in selected mushroom species growing in the same unpolluted areas in Poland. J Environ Sci Health B 50:659-666. doi:10.1080/ 03601234.2015.1038959

Mleczek M, Siwulski M, Mikołajczak P, Gąsecka M, Sobieralski K, Szymańczyk M, Goliński P (2015b) Content of selected elements and possibility to grow Boletus badius fruiting bodies in extremely polluted wastes. J Environ Sci Health A 50:767-775. doi:10.1080/ 10934529.2015.1012014

Mleczek M, Niedzielski P, Kalač P, Siwulski M, Rzymski P, Gąsecka M (2016) Levels of platinum group elements and rare earth elements in wild mushroom species growing near a busy trunk road. Food Addit Contam A 33:86-94. doi:10.1080/19440049.2015.1114684

Niedzielski P, Mleczek M, Magdziak Z, Siwulski M, Kozak L (2013) Selected arsenic species: As(III), As(V) and dimethylarsenic acid (DMAA) in Xerocomus badius fruiting bodies. Food Chem 141: 3571-3577. doi:10.1016/j.foodchem.2013.06.103

PN-ISO 11466:2002 Jakość gleby. Ekstrakcja pierwiastków śladowych rozpuszczalnych w wodzie królewskiej. Soil quality. The extraction of trace elements soluble in aqua regia.

PN-ISO 1265+AC1:1997 Jakość gleby. Oznaczanie przewodności elektrolitycznej. (Soil quality. Determination of electrolytic conduction.) [in Polish]

PN-ISO 10390:1997 Jakość gleby. Oznaczanie pH. (Soil quality. Determination of $\mathrm{pH}$.) [in Polish]

PN-ISO 11465:1999 Jakość gleby. Oznaczanie zawartości suchej masy i wody w glebie w przeliczeniu na suchą mase gleby. Metoda wagowa. (Soil quality. Determination of dry matter and water content on a mass basis. Gravimetric method.) [in Polish] 
PN-ISO 14235:2003 Jakość gleby. Oznaczanie zawartości węgla organicznego przez utlenianie dwuchromianem(VI) w środowisku kwasu siarkowego(VI). (Soil quality. Determination of organic carbon by sulfochromic oxidation.) [in Polish]

Radulescu C, Stihi C, Busuioc G, Gheboianu AI, Popescu IV (2010) Studies concerning heavy metals bioaccumulation of wild edible mushrooms from industrial area by using spectrometric techniques. Bull Environ Contam Toxicol 84:641-646. doi:10.1007/s00128010-9976-1

Salminen R et al (eds) (2005) Geochemical Atlas of Europe. Part 1background information, methodology and maps. Geological survey of Finland. Otamedia Oy, Espoo

Sarikurkcu C, Tepe B, Solak MH, Cetinkaya S (2012) Metal concentration of wild edible mushrooms from Turkey. Ecol Food Nutr 51: 346-363. doi:10.1080/03670244.2012.674448

Sarikurkcu C, Tepe B, Kocak MS, Uren MC (2015) Metal concentration and antioxidant activity of edible mushrooms from Turkey. Food Chem 175:549-555. doi:10.1016/j.foodchem.2014.12.019

Severoglu Z, Sumer S, Yalcin B, Leblebici Z, Aksoy A (2013) Trace metal levels in edible wild fungi. Int $\mathrm{J}$ Environ Sci Technol 10: 295-304. doi:10.1007/s13762-012-0139-2

Sun L, Liu G, Yang M, Zhuang Y (2012) Bioaccessibility of cadmium in fresh and cooked Agaricus blazei Murill assessed by in vitro biomimetic digestion system. Food Chem Toxicol 50:1729-1733. doi:10. 1016/j.fct.2012.02.044
Svoboda L, Kalač P, Špička J, Janoušková D (2002) Leaching of cadmium, lead and mercury from fresh and differently preserved edible mushroom, Xerocomus badius, during soaking and boiling. Food Chem 79:41-45

Svoboda L, Havlíčková B, Kalač P (2006) Contents of cadmium, mercury and lead in edible mushrooms growing in a historical silvermining area. Food Chem 96:580-585. doi:10.1016/j.foodchem. 2005.03.012

Wondratschek I, Röder U (1993) Monitoring of heavy metals in soils by higher fungi. In: Markert B (ed) Plants as biomonitors. Indicators for heavy metals in the terrestrial environment. $\mathrm{VCH}$, Weinheim, pp 345-363

Yin LL, Shi GQ, Tian Q, Shen T, Ji YQ, Zeng G (2012) Determination of the metals by ICP-MS in wild mushrooms from Yunnan, China. J Food Sci 77:T151-T155. doi:10.1111/j.1750-3841.2012.02810.x

Zeng X, Suwandi J, Fuller J, Doronilla A, Ng K (2012) Antioxidant capacity and mineral contents of edible wild Australian mushrooms. Food Sci Technol Int 18:367-379. doi:10.1177/1082013211427993

Zhang D, Frankowska A, Jarzyńska G, Kojta AK, Drewnowska M, Wydmańska D, Bielawski L, Wang J, Falandysz J (2010) Metals of King Bolete (Boletus edulis) Bull.:Fr. collected at the same site over two years. Afr J Agric Res 5:3050-3055

Zhu F, Qu L, Fan W, Qiao M, Hao H, Wang X (2011) Assessment of heavy metals in some wild edible mushrooms collected from Yunnan Province, China. Environ Monit Assess 179:191-199. doi: 10.1007/s10661-010-1728-5 